\title{
PENERAPAN MODEL PEMBELAJARAN GROUP INVESTIGATION DALAM MENINGKATKAN MOTIVASI DAN HASIL BELAJAR SISWA PADA MATA PELAJARAN IPS DI KELAS VI SD LABORATORIUM UNG KOTA SELATAN KOTA GORONTALO
}

Oleh :

Fandi H. Binggo

Program Pascasarjana Program Studi Pendidikan Dasar Konsentrasi IPS Universitas Negeri Gorontalo

\begin{abstract}
ABSTRAK
Fandi H. Binggo. 2015. Penerapan Model Pembelajaran Group Investigation Dalam Meningkatkan Motivasi dan Hasil Belajar Siswa Pada Mata Pelajaran IPS di Kelas VI SD Laboratorium UNG Kota Selatan Kota Gorontalo. Tesis. Program Studi Magister Pendidikan Dasar, Program Pascasarjana, Universitas Negeri Gorontalo. Pembimbing 1 Prof. Dr. Hj. Asna Aneta, M.Si dan Pembimbing II Dr. H. Rauf Hatu, M.Si.

Permasalahan dalam penelitian ini adalah (1) Apakah penerapan model pembelajaran Group Investigation dapat meningkatkan motivasi dan hasil belajar siswa pada mata pelajaran IPS di kelas VI SD Laboratorium UNG Kota Selatan Kota Gorontalo?. (2) Apakah penerapan model pembelajaran Group Investigation dapat meningkatkan hasil belajar siswa pada mata pelajaran IPS di kelas VI SD Laboratorium UNG Kota Selatan Kota Gorontalo?. Penelitian ini bertujuan (1) Untuk meningkatkan motivasi belajar siswa pada mata pelajaran IPS di kelas VI SD Laboratorium UNG Kota Selatan Kota Gorontalo melalui model pembelajaran Group Investigation. (2) Untuk meningkatkan hasil belajar siswa pada mata pelajaran IPS di kelas VI SD Laboratorium UNG Kota Selatan Kota Gorontalo melalui model pembelajaran Group Investigation. Teknik pengumpulan data dalam penelitian ini adalah: 1) Lembar pengamatan kegiatan guru dan siswa selama proses pembelajaran, 2) Lembar pengamatan motivasi belajar siswa dan 3) Tes hasil belajar siswa.

Metode yang digunakan dalam penelitian ini adalah metode penelitian tindakan kelas yang dilaksanakan dalam dua siklus dan setiap siklus terdiri dari 2 kali pertemuan. Sebagai kesimpulan dari penelitian ini adalah: Penggunaan Model Pembelajaran Group Investigation dapat meningkatkan Motivasi dan Hasil Belajar Siswa pada mata pelajaran IPS khususnya di kelas VI SD Laboratorium UNG Kota Selatan Kota Gorontalo, hal tersebut didukung dengan hasil penelitian yakni: 1) Hasil pengamatan Motivasi Belajar Siswa, ketuntasan pada siklus I sangat baik dan baik mencapai $5 \%$ dan pada siklus II meningkat menjadi $100 \%$. 2) Hasil Belajar Siswa pada observasi awal $46 \%$ meningkat pada siklus I mencapai 52,50 \% dan pada siklus II meningkat menjadi $90 \%$. 3) Hasil pengamatan kegiatan guru dalam pembelajaran, pada siklus I kriteria sangat baik dan baik mencapai $28 \%$ dan pada siklus II meningkat menjadi $86 \%$. 4) Hasil pengamatan aktivitas siswa dalam pembelajaran, pada siklus I pada kriteria sangat baik dan baik mencapai $33 \%$ dan pada siklus II menjadi $86 \%$. Berdasarkan hasil capaian persentase tersebut dinyatakan bahwa kriteria tuntas atau indikator tercapai.
\end{abstract}

Kata Kunci: Motivasi, Hasil Belajar, Group Investigation 


\begin{abstract}
Fandi H. Binggo. 2015. The Implementation of Group Investigation in Improving Students' Motivation and Learning Achievement in Social Sciences Subject at Class VI of SD Laboratorium UNG Kota Selatan, Gorontalo City. Thesis. Study Program of Master of Elementary Education, Postgraduate Program, State University of Gorontalo. The principal supervisor was Prof. Dr. Hj. Asna Aneta, M.Si and the co-supervisor was Dr. H. Rauf Hatu, M.Si.

The problem statements of this research were (1) does group investigation learning model increase students' learning motivation in Social Sciences subject at class VI of SD Laboratorium UNG Kota Selatan, Gorontalo City? (2) Does Group Investigation learning model increase students' learning achievement in Social Sciences subject at class VI of SD Laboratorium UNG Kota Selatan, Gorontalo City. This research aimed at (1) increasing students' learning motivation in Social Sciences subject at class VI of SD Laboratorium UNG Kota Selatan, Gorontalo City through Group Investigation learning model, and (2) increasing students' learning achievement in Social Sciences subject at class VI of SD Laboratorium UNG Kota Selatan, Gorontalo City through Group Investigation learning model. The techniques of data collection were teacher and student's activity observation sheet during learning process, teacher and student's motivation observation sheet, and test of students' learning achievement.

The method of this research was classroom action research that consisted of two cycles in which each cycle consisted of 2 meetings. It concleded that Group Investigation learning model increased students' motivation and learning achievement in Social Sciences subject particularly at Class VI of SD Laboratorium UNG Kota Selatan, Gorontalo City. The result can observed as follow: 1) The percentage of observation result of students' learning motivation which categorized as good and excellent increased from 5\% in cycle I to $100 \%$ in cycle II, 2) students' learning achievement in initial observation which was only $46 \%$ increased to $52,50 \%$ in cycle I and became $90 \%$ in cycle II, 3) the observation result of teacher's activity in learning precess which was categorized as good and excellent increased from $28 \%$ in cycle I to $86 \%$ in cycle II, 4) the observation result of student's activity in learning precess which was categorized as good and excellent increased from $33 \%$ in cycle I to $86 \%$ in cycle II. Based in the percentage of the achievement, it can be stated that the criteria was complete or the indicator was achieved.
\end{abstract}

Keywords: Motivation, Learning Achievement, Group Investigation 


\section{PENDAHULUAN}

Ilmu Pengetahuan Sosial sebagai disiplin operasional yang efektif dan memperhatikan studi tentang manusia di masyarakat, dalam situasi global saat ini dapat memainkan peranan yang sangat penting namun demikian berdasarkan data keberadaannya dalam mengajarkan IPS didominasi oleh proses belajar mengajar dengan menggunakan buku teks dan cara penyampaian materinya masih bersifat tradisional yaitu hanya dengan menggunakan metode ceramah saja.

Berdasarkan pengalaman peneliti di lapangan kondisi serupa dialami pula oleh siswa pada sekolah tempat peneliti mengajar di SD Laboratorium UNG Kota Gorontalo. Hal tersebut dapat dilihat dari standar ketuntasan minimal (KKM) 75 yang telah ditentukan tidak sesuai dengan target yang dicapai, dengan melihat data tahun pada tahun 2014, 13 orang siswa mencapai nilai KKM dengan persentase $46 \%$ sedangkan yang belum tuntas 15 orang atau $54 \%$. Hal tersebut terjadi karena diduga oleh model pembelajaran yang guru lakukan hanya bersifat konvensional. Sehingga tidak adanya antusias siswa disaat belajar, cepat bosan, cepat putus asa ketika menghadapi kesulitan dan tidak tekun ketika mengerjakan tugas. Dengan demikian dari hasil observasi motivasi dan hasil siswa masih rendah.

\section{KAJIAN TEORI}

\section{Hakikat Motivasi Belajar}

\section{a. Pengertian Motivasi}

Motivasi berasal dari kata motif yang dapat diartikan sebagai kekuatan yang terdapat dalam diri individu, yang menyebabkan individu tersebut bertindak atau berbuat (Uno, 2013:3). Motif tidak dapat diamati secara langsung, tetapi dapat diinterpretasikan dalam tingkah lakunya berupa rangsangan, dorongan, atau pembangkit tenaga munculnya suatu tingkah laku tertentu. Menurut Uno (2013:3) motivasi merupakan dorongan yang terdapat dalam diri seseorang untuk berusaha mengadakan perubahan tingkah laku yang lebih baik dalam memenuhi kebutuhannya.

Menurut Makmun (2007: 37) motivasi merupakan: 1) Suatu kekuatan (power) atau tenaga (forces) atau daya (energy); atau 2) Suatu keadaan yang kompleks (a complex state) dan kesiapsediaan (preparatory set) dalam diri individu (organisme) untuk bergerak (to move, motion, motive) ke arah tujuan tertentu, baik disadari maupun tidak disadari.

Suryabrata (2011: 70) mengemukakan motif adalah keadaan dalam pribadi orang yang mendorong individu untuk melakukan aktiviatas-aktivitas tertentu guna mencapai suatu tujuan. Motif manusia merupakan dorongan, hasrat, keingianan dan tenaga 
penggerak lainnya, yang berasal dari dalam dirinya,untuk melakukan sesuatu menurut Sobour (2003: 265).

\section{b. Motivasi Belajar Siswa}

Uno (2013:23) mengungkapkan bahwa motivasi dan belajar adalah merupakan dua hal yang saling mempengaruhi. Belajar adalah perubahan tingkah laku secara relatif permanen dan secara potensial terjadi sebagai hasil dari praktek atau penguatan (reinforced practice) yang dilandasi dengan tujuan untuk mencapai tujuan tertentu.

Selain itu Uno (2013: 23) menjelaskan motivasi belajar dapat timbul karena diakibatkan oleh faktor intrinsik yang berupa hasrat dan keinginan berhasil dan dorongan kebutuhan belajar, harapan akan bercita-cita. Sedangkan faktor ekstrinsiknya adalah adanya penghargaan, lingkungan belajar yang kondusif dan kegiatan belajar yang menarik, namun harus diingat kedua faktor tersebut disebabkan oleh rangsangan tertentu, sehingga seseorang berkeinginan untuk melakukan aktivitas belajar yang lebih giat dan semangat. Indikator motivasi belajar itu dapat diklasifikasikan: (1) adanya hasrat dan keinginan berhasil; (2) adanya dorongan dan kebutuhan dalam belajar; (3) adanya harapan dan cita-cita masa depan; (4) adanya penghargaan dalam belajar; (5) adanya kegiatan yang menarik dalam belajar; (6) adanya lingkungan belajar yang kondusif sehingga memungkinkan seorang siswa dapat belajar dengan baik.

\section{Hasil Belajar Siswa}

\section{a. Pengertian Belajar}

Belajar merupakan usaha manusia membangun pengetahuan dalam dirinya. Serangkaian dengan keinginan manusia yang lebih baik, maka banyak usaha yang dilakukan untuk meningkatkan kualitas belajar. Kata belajar berarti berusaha memperoleh kepandaian atau ilmu KBBI dalam (Sunendar, 2009:4). Trianto (2011:16) Belajar secara umum diartikan sebagai perubahan pada individu yang terjadi melalui pengalaman, dan bukan karena pertumbuhan atau perkembangan tubuhnya atau karakteristik seseorang sejak lahir.

Abdurrahman (2003:28), belajar merupakan suatu proses dari seorang individu yang berupaya mencapai tujuan belajar atau biasa disebut hasil belajar, yaitu suatu bentuk perubahan perilaku yang relatif menetap.

\section{b. Pengertian Hasil Belajar}

Menurut Sri Rumini, dkk (1995:61) hasil belajar siswa merupakan kapasitas manusia yang nampak dalam tingkah laku. Tingkah laku yang dimaksud adalah tingkah laku siswa yang ditampilkan yang berkaitan dengan hasil belajar dengan memberikan gambaran yang lebih nyata, hal ini tentunya berkaitan dengan hasil dan proses belajar di 
sekolah. Menurut Sagala (2003:23) yang menyatakan bahwa hasil belajar adalah berupa keterampilan-keterampilan intelektual yang memungkinkan seseorang berinteraksi. Pendapat tersebut di pertegas kembali oleh Hamalik (2009:189) bahwa hasil belajar adalah terjadi perubahan tingkah laku pada diri siswa yang dapat diamati dan diukur dalam bentuk perubahan tingkah laku pada diri siswa yang dapat diamati dan diukur dalam bentuk perubahan pengetahuan, sikap, dan keterampilan.

Kusnandar (2007:337) hasil belajar adalah kemampuan siswa dalam memenuhi suatu tahapan pencapaian pengalaman belajar dalam satu kompetensi dasar. Hasil belajar dalam silabus berfungsi sebagai petunjuk tentang perubahan perilaku yang akan dicapai oleh siswa sehubungan dengan kegiatan belajar yang dilakukan, sesuai dengan kompetensi dasar dan materi standar yang dikaji. Hasil belajar bisa berbentuk pengetahuan, keterampilan maupun sikap.

Uzer dan Setiawati (2000: 8) mengatakan bahwa hasil belajar siswa adalah pencapaian tujuan pembelajaran melalui suatu proses belajar mengajar tentang bahan pengajaran. Kemudian menurut Muhibbinsyah (2003: 136) bahwa pada prinsipnya, pengungkapan hasil belajar yang ideal meliputi segenap ranah psikologis yang berubah sebagai akibat pengalaman dan proses belajar siswa. Namun demikian, pengungkapan perubahan tingkah laku seluruh ranah itu, khususnya ranah rasa siswa, sangat sulit. Hal ini disebabkan perubahan hasil belajar itu ada yang bersifat intangible (tidak berwujud secara nyata).

\section{Pembelajaran Kooperatif}

(Cooperative Learning) teknik Group Investigation

\section{a. Pengertian Pembelajaran Kooperatif}

Menurut Slavin (dalam Isjoni, 2009:15) mengemukakan cooperative learning adalah suatu model pembelaaran dimana dalam sistem belajar dan bekerja dalam kelompokkelompok kecil yang berjumlah $4-6$ orang secara kolaboratif sehingga dapat merangsang siswa lebih bergairah dalam belajar. Sama halnya dengan yang dikemukakan oleh Riyanto (2010:267) bahwa pembelajaran kooperatif adalah model pembelajaran yang dirancang untuk membelajarkan kecakapan akademik, sekaligus keterampilan sosial termasuk interpersonal skill.

Menurut Nurhadi (2004:112) Pembelajaran kooperatif adalah suatu sistem yang didalamnya terdapat elemen-elemen yang saling terkait. Elemen-elemen itu adalah: (1) saling ketergantungan positif, pembelajaran kooperatif, menciptakan suatu yang mendorong agar siswa merasa saling membutuhkan. (2) Interaksi tatap muka, Interaksi tatap muka dalam kelompok 
sehingga dapat berdialog. (3) Akuntabilitas

individual, pembelajaran kooperatif menampilkan wujudnya dalam belajar kelompok.

\section{b. Model Pembelajaran Group Investigation (GI)}

Slavin (2010:215) bahwa dalam proses pembelajaran model kooperatif Group Investigation terjadi peningkatan kemampuan dalam melakukan analisis dan sintesis terhadap segala informasi, sehingga penguasaan akan materi pelajaran menjadi lebih baik. Dengan melihat proses belajar seperti itu, siswa dapat membangun sendiri pengetahuannya dan secara langsung menggunakan pengetahuannya untuk membahas permasalahan yang diangkat, sehingga pembelajaran menjadi sangat bermakna.

Menurut Putra (2003:39), "Model Group Investigation (GI) atau investigasi kelompok telah digunakan dalam berbagai bidang studi dan berbagai tingkat usia" pada dasarnya model ini dirancang untuk membimbing para siswa mendefinisikan masalah, mengeksplorasi berbagai cakrawala mengenai masalah itu, mengumpulkan data yang relevan, mengembangkannya dan mengetes hipotesis.

\section{Hipotesis Tindakan}

Berdasarkan permasalahan penelitian dan kajian teori, maka dibuatkan hipotesis tindakan sebagai berikut :

1) Jika pada pembelajaran IPS diterapkan model pembelajaran Group Investigation, maka motivasi belajar siswa kelas VI SD Laboratorium UNG akan meningkat.

2) Jika pada pembelajaran IPS diterapkan model pembelajaran Group Investigation, maka hasil belajar siswa kelas VI SD Laboratorium UNG akan meningkat.

\section{Metode Penelitian}

\section{Setting Penelitian}

Pelaksanaan penelitian ini bertempat di SD Laboratorium UNG. Tempat pelaksanaan penelitian ini merupakan salah satu sekolah di Kota Gorontalo tepatnya di Kelurahan Limba U II kecamatan Kota Selatan Kota Gorontalo. Sekolah ini merupakan sekolah dari Yayasan Tridharma Akademika Universitas Negeri Gorontalo yang berdiri sejak tahun 2003. Pelaksanaan penelitian ini dilaksanakan dalam kurun waktu 3 bulan yakni dimulai dari bulan Maret sampai dengan bulan Mei 2015 tepatnya semester 2 .

\section{Jenis Penelitian}

Penelitian ini merupakan Penelitian Tindakan Kelas (PTK) yang dilakukan sebagai upaya dalam menerapkan model 
pembelajaran Group Investigation untuk meningkatkan motivasi dan hasil belajar siswa kelas IV SD Laboratorium UNG Kota Selatan Kota Gorontalo. Dalam penelitian ini dibagi dalam 3 variabel yakni variabel input, variabel proses dan variabel output.

\section{Desain Tindakan}

Menurut Arikunto (2007:16) secara garis besar ada empat tahapan dalam penelitian tindakan kelas yaitu: perencanaan, pelaksanaan, pengamatan, dan refleksi yang akan dilaksanakan dalam dua siklus. Berikut adalah desain penelitian kelas yang digunakan peneliti yaitu:

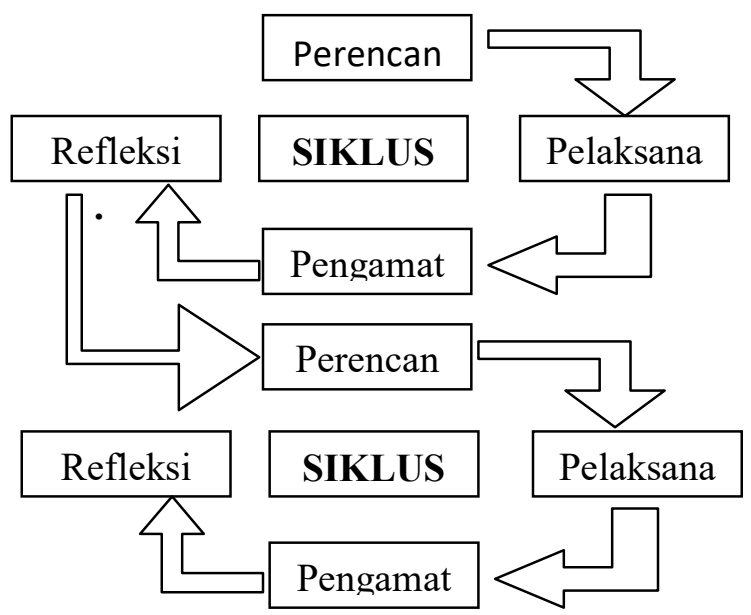

\section{Gambar. Desain Penelitian Tindakan} Kelas

\section{Teknik Pengumpulan Data}

Untuk mencari data dalam penelitian ini, peneliti menggunakan beberapa teknik pengumpulan data antara lain:
1) Observasi

Dalam observasi peneliti mengumpulkan data dengan cara mengamati dan mencatat hal-hal penting yang terjadi pada saat proses kegiatan belajar mengajar yang dilangsungkan oleh guru.

2) Dokumentasi

Dokumentasi merupakan teknik dalam mengumpulkan data pada saat berlangsungnya proses pembelajaran yang meliputi lembar penilaian movitasi belajar, hasil belajar dan kegiatan guru dalam melaksanaan proses pembelajaran serta dokumentasi berupa foto dan video disaat pembelajaran berlangsung.

3) Tes

Tes yaitu lembaran pertanyaan yang diajukan kepada siswa setelah melaksanakan kegiatan pembelajaran (kegiatan pelaksanaan evaluasi pada akhir pelaksanaan kegiatan pembelajaran). Tes yang digunakan tes tertulis.

\section{Analisis Data dan Refleksi}

Penentuan keberhasilan tindakan dalam pembelajaran dengan model pembelajaran group investigation dilakukan dengan menggunakan analisis persentase 
seperti yang diadaptasi dari Sudjana

(2009:86) yang kriterianya sebagai berikut

keberhasilan kegiatan guru dan siswa

melalui model pembelajaran Group

Investigation.

$$
\frac{\text { Jumla Aspek Yang Terlaksana }}{\text { Jum semua Aspek }} \text { X } 100 \%
$$

Setelah data penelitian dikumpulkan data tersebut akan diolah dengan teknik kuantitatif yang berbentuk angka-angka dengan rumus persentase seperti di bawah ini:

Rumus Presentase : $\quad \mathrm{P}=\frac{E}{N} \times 100$

Keterangan :

$\mathrm{P} \quad=$ Presentase yang dicari

$\mathrm{F} \quad=$ Jumlah siswa yang dianggap bisa

$\mathrm{N}=$ Jumlah seluruh anak

$100=$ Angka konstan (\%), (Sudjana (2009:86)

\section{Indikator Keberhasilan}

Untuk mengetahui keberhasilan, pencapaian tujuan dalam penelitian di Kelas VI SD Laboratorium UNG Kota Selatan Kota Gorontalo, maka motivasi dan hasil belajar siswa akan meningkat dengan acuan sebagai berikut:

a. Hasil pengamatan kegiatan guru yang termasuk pada kategori Sangat Baik (SB) dan Baik (B) menjadi minimal $80 \%$. b. Hasil pengamatan aktivitas siswa yang termasuk pada kategori Sangat Baik (SB) dan Baik (B) menjadi minimal $80 \%$.

c. Hasil pengamatan motivasi belajar siswa yang termasuk kategori Sangat Baik (SB) dan Baik (B) minimal 85 $\%$.

d. Jumlah siswa yang memperoleh nilai minimal 75 meningkat dari $46 \%$ menjadi minimal $85 \%$.

\section{Hasil Penelitian dan Pembahasan}

\section{Observasi Awal}

Berdasarkan data yang diperoleh pada pembelajaran IPS khususnya materi perdagangan internasional dalam hal ini kegiatan perdagangan internasional pada tahun 2013, 11 orang siswa tuntas dengan persentasenya $44 \%$ sedangkan 14 orang tidak tuntas atau 56 \%. Pada tahun 2014 siswa yang tuntas pada materi ini berjumlah 13 orang dengan persentase $46 \%$, sedangkan 15 orang diantaranya tidak tuntas dengan persentase $54 \%$.

\section{Pelaksanaan Penelitian Siklus I}

\section{Hasil Pengamatan Kegiatan Guru Siklus I}

Berdasarkan hasil penilaian kegiatan guru dalam pembelajaran pada siklus I pertemuan ke- 1 dan ke- 2 belum sesuai dengan yang 
diharapkan. Berikut gambaran rekapitulasi

hasil pengamatan kegiatan guru dalam proses pembelajaran.

Tabel 4.3. Rekapitulasi Hasil Pengamatan kegiatan Guru Dalam Proses Pembelajaran Siklus I

\begin{tabular}{|c|c|c|c|c|c|}
\hline \multirow{2}{*}{$\begin{array}{l}\mathbf{N} \\
\mathbf{0}\end{array}$} & \multirow{2}{*}{$\begin{array}{c}\text { Katego } \\
\text { ri }\end{array}$} & \multicolumn{2}{|c|}{$\begin{array}{l}\text { Pertemu } \\
\text { an }\end{array}$} & \multirow{2}{*}{$\underset{\text { ta }}{\text { Rera }}$} & \multirow{2}{*}{$\begin{array}{c}\text { Keteran } \\
\text { gan }\end{array}$} \\
\hline & & 1 & 2 & & \\
\hline 1 & $\begin{array}{l}\text { Sangat } \\
\text { Baik }\end{array}$ & - & $\begin{array}{l}12 \\
\%\end{array}$ & $6 \%$ & \multirow{2}{*}{$\begin{array}{c}\text { Sangat } \\
\text { Baik }+ \\
\text { Baik }= \\
28 \%\end{array}$} \\
\hline 2 & Baik & $\begin{array}{l}20 \\
\%\end{array}$ & $\begin{array}{l}24 \\
\%\end{array}$ & $22 \%$ & \\
\hline 3 & Cukup & $\begin{array}{l}40 \\
\%\end{array}$ & $\begin{array}{l}36 \\
\%\end{array}$ & $38 \%$ & \multirow{2}{*}{$\begin{array}{l}\text { Cukup + } \\
\text { Kurang } \\
=72 \%\end{array}$} \\
\hline 4 & Kurang & $\begin{array}{l}40 \\
\%\end{array}$ & $\begin{array}{l}28 \\
\%\end{array}$ & $34 \%$ & \\
\hline & $\begin{array}{l}\text { Present } \\
\text { ase }\end{array}$ & 100 & $\begin{array}{c}10 \\
0\end{array}$ & 100 & \\
\hline
\end{tabular}

Berdasarkan data pada tabel 4.3 rekapitulasi hasil pengamatan kegiatan guru dalam proses pembelajaran Siklus I pertemua ke-1 dan ke- 2, tampak dalam proses pembelajaran guru kurang mampu mengelolah pembelajaran dengan baik. Hasil rata-rata capaian yang diperoleh pada siklus I masih belum sesuai dengan ketuntasan yang diharapkan. Hasil rata-rata nilai yang diperoleh pada setiap aspek yakni pada kategori sangat baik memperoleh nilai rata-rata $6 \%$, kategori baik $22 \%$, kategori cukup $38 \%$, dan kategori kurang $34 \%$. Dengan demikian pelaksanaan kegiatan guru dalam pembelajaran pada siklus I belum tercapai.

\section{Hasil Pengamatan Aktivitas Siswa Siklus I}

Pengamatan aktivitas siswa dalam pembelajaran yang telah dicapai pada siklus I pertemuan ke- 1 dan ke- 2 direkapitulasi pada tabel 4.6 berikut.

Tabel 4.6. Rekapitulasi Hasil Pengamatan Aktivitas Siswa Dalam Proses Pembelajaran Siklus I

\begin{tabular}{|c|c|c|c|c|c|}
\hline \multirow{2}{*}{$\begin{array}{l}\mathbf{N} \\
\mathbf{0}\end{array}$} & \multirow{2}{*}{$\begin{array}{c}\text { Katego } \\
\text { ri }\end{array}$} & \multicolumn{2}{|c|}{$\begin{array}{c}\text { Pertemu } \\
\text { an }\end{array}$} & \multirow{2}{*}{$\begin{array}{c}\text { Rera } \\
\text { ta }\end{array}$} & \multirow{2}{*}{$\begin{array}{c}\text { Keteran } \\
\text { gan }\end{array}$} \\
\hline & & 1 & 2 & & \\
\hline 1 & $\begin{array}{l}\text { Sangat } \\
\text { Baik }\end{array}$ & - & $\begin{array}{l}23 \\
\%\end{array}$ & $12 \%$ & \multirow{2}{*}{$\begin{array}{c}\text { Sangat } \\
\text { Baik + } \\
\text { Baik }= \\
33 \%\end{array}$} \\
\hline 2 & Baik & $\begin{array}{l}23 \\
\% \\
\end{array}$ & $\begin{array}{l}18 \\
\% \\
\end{array}$ & $21 \%$ & \\
\hline 3 & Cukup & $\begin{array}{l}36 \\
\%\end{array}$ & $\begin{array}{l}41 \\
\%\end{array}$ & $38 \%$ & \multirow{2}{*}{$\begin{array}{l}\text { Cukup }+ \\
\text { Kurang } \\
=67 \%\end{array}$} \\
\hline 4 & Kurang & $\begin{array}{l}41 \\
\%\end{array}$ & $\begin{array}{l}18 \\
\%\end{array}$ & $29 \%$ & \\
\hline & $\begin{array}{l}\text { Present } \\
\text { ase }\end{array}$ & 100 & $\begin{array}{c}10 \\
0\end{array}$ & 100 & \\
\hline
\end{tabular}

Berdasarkan data pada tabel 4.6 di atas tampak siswa belum sepenuhnya berperan aktif dalam proses pembelajaran siklus I pertemua ke- 1 dan ke- 2. Hal ini terlihat dalam kegiatan siswa sebagian besar masih mencapai kategori cukup dan kurang dengan nilai rata-rata dari seluruh pertemuan pembelajaran siklus I kategori sangat baik hanya mencapai $12 \%$, kategori baik $21 \%$, kategori cukup $38 \%$ dan kategori kurang $29 \%$.

Berdasarkan data pada tabel 4.6 di atas tampak aktivitas siswa dalam proses pembelajaran siklus I dapat disimpulkan bahwa siswa belum menunjukkan perhatian 
dengan model pembelajaran Group Investigation yang digunakan hal dikarenakan siswa belum terbiasa dengan model pembelajaran yang digunakan, siswa juga kurang melibatkan diri dalam proses belajar mengajar hanya sebagian saja yang aktif sedangkan yang lain belum menunjukkan perhatian yang baik ketika pembelajaran.

\section{Hasil Pengamatan Motivasi Belajar} Siswa Siklus I

Berikut rekapitulasi capaian hasil pengamatan motivasi belajar siswa siklus I pertemuan ke- 1 dan 2 pada tabel 4.9 di bawah ini.

Tabel 4.9. Rekapitulasi

Hasil

Pengamatan Motivasi Belajar Siswa Siklus I

\begin{tabular}{|c|c|c|c|c|c|}
\hline \multirow{2}{*}{$\begin{array}{c}\mathbf{N} \\
\mathbf{0}\end{array}$} & \multirow{2}{*}{$\begin{array}{c}\text { Kateg } \\
\text { ori }\end{array}$} & \multicolumn{2}{|c|}{$\begin{array}{c}\text { Pertemu } \\
\text { an }\end{array}$} & \multirow{2}{*}{$\begin{array}{c}\text { Rera } \\
\text { ta }\end{array}$} & \multirow{2}{*}{$\begin{array}{c}\text { Keteran } \\
\text { gan }\end{array}$} \\
\hline & & 1 & 2 & & \\
\hline 1 & $\begin{array}{l}\text { Sangat } \\
\text { Baik }\end{array}$ & - & - & - & \multirow{2}{*}{$\begin{array}{c}\text { Sangat } \\
\text { Baik }+ \\
\text { Baik }=5 \\
\%\end{array}$} \\
\hline 2 & Baik & - & $\begin{array}{l}10 \\
\%\end{array}$ & $5 \%$ & \\
\hline 3 & Cukup & $\begin{array}{l}75 \\
\% \\
\end{array}$ & $\begin{array}{l}80 \\
\% \\
\end{array}$ & $\begin{array}{c}77,50 \\
\% \\
\end{array}$ & \multirow{2}{*}{$\begin{array}{l}\text { Cukup + } \\
\text { Kurang } \\
=95 \%\end{array}$} \\
\hline 4 & $\begin{array}{l}\text { Kuran } \\
\text { g }\end{array}$ & $\begin{array}{l}25 \\
\%\end{array}$ & $\begin{array}{l}10 \\
\%\end{array}$ & $\begin{array}{c}17,50 \\
\%\end{array}$ & \\
\hline
\end{tabular}

Hasil rekapitulasi pengamatan motivasi belajar siswa siklus I tabel 4.9 menunjukkan bahwa pertemuan ke- 1 dan 2 belum maksimal karena sebagian besar masih mencapai kategori cukup dan kurang dimana nilai rata-rata dari seluruh pertemuan pada pembelajaran siklus I kategori sangat baik dan kategori baik hanya mencapai nilai rata-rata $5 \%$, sedangkan untuk kategori cukup dan kurang berada pada tingkat yang lebih tinggi yaitu $95 \%$. Berdasarkan data pada tabel 4.9 di atas tampak bahwa motivasi belajar siswa dalam proses pembelajaran terhadap materi perdagangan internasional dengan model Group Investigation (GI) belum maksimal.

\section{Hasil Belajar Siswa Siklus I}

Berikut disajikan rekapitulasi hasil belajar siswa siklus I yang terangkum dalam tabel 4.10 berikut ini.

Tabel 4.10 Rekapitulasi Hasil Belajar Siswa Siklus I

\begin{tabular}{|c|c|c|c|c|c|c|}
\hline \multirow[b]{2}{*}{ No } & \multicolumn{2}{|c|}{$\begin{array}{c}\text { Jumlah } \\
\text { Capaian Siswa }\end{array}$} & \multirow{2}{*}{$\begin{array}{c}\text { Renta } \\
\text { ng } \\
\text { Nilai }\end{array}$} & \multicolumn{2}{|c|}{ Persentase } & \multirow[b]{2}{*}{ Ket } \\
\hline & $\begin{array}{l}\text { Perte } \\
\text { muan } \\
\text { ke- } 1 \\
\end{array}$ & $\begin{array}{c}\text { Pertem } \\
\text { uan } \\
\text { Ke- } 2\end{array}$ & & $\begin{array}{c}\text { Pertem } \\
\text { uan } \\
\text { ke- } 1 \\
\end{array}$ & $\begin{array}{c}\text { Pertem } \\
\text { uan } \\
\text { Ke- } 2\end{array}$ & \\
\hline 1 & $\begin{array}{c}1 \\
\text { orang }\end{array}$ & $\begin{array}{c}2 \\
\text { orang }\end{array}$ & $\begin{array}{l}90- \\
100\end{array}$ & $5 \%$ & $10 \%$ & \multirow{7}{*}{$\begin{array}{c}\text { Berh } \\
\text { asil }\end{array}$} \\
\hline 2 & $\begin{array}{c}3 \\
\text { orang }\end{array}$ & $\begin{array}{c}2 \\
\text { orang }\end{array}$ & $\begin{array}{c}80- \\
89\end{array}$ & $15 \%$ & $10 \%$ & \\
\hline 3 & $\begin{array}{c}5 \\
\text { orang }\end{array}$ & $\begin{array}{c}8 \\
\text { orang }\end{array}$ & $\begin{array}{c}70- \\
79\end{array}$ & $25 \%$ & $35 \%$ & \\
\hline 4 & $\begin{array}{c}7 \\
\text { orang }\end{array}$ & $\begin{array}{c}7 \\
\text { orang }\end{array}$ & $\begin{array}{c}60- \\
69\end{array}$ & $35 \%$ & $40 \%$ & \\
\hline 5 & $\begin{array}{c}4 \\
\text { orang }\end{array}$ & $\begin{array}{c}1 \\
\text { orang }\end{array}$ & $\begin{array}{c}50- \\
59\end{array}$ & $20 \%$ & $5 \%$ & \\
\hline \multicolumn{4}{|c|}{ Ketuntasan Klasikal } & $45 \%$ & $60 \%$ & \\
\hline \multicolumn{4}{|c|}{ Nilai rata-rata kelas } & $68 \%$ & $71 \%$ & \\
\hline
\end{tabular}

Berdasarkan tabel 4.10 di atas, dapat diketahui bahwa hasil belajar siswa siklus I pertemua ke- 1 dan 2 belum mencapai indikator keberhasilan yakni $70 \%$ dari ratarata kelas. Hasil belajar pada siklus I pertemuan ke- 1 siswa yang memperoleh 
nilai $\geq 75$ sebanyak 9 orang dengan persentase ketuntasan $45 \%$, siswa yang memperoleh nilai $<75$ sebanyak 11 orang siswa dengan persentase $55 \%$, sedangkan daya serap siswa pada pertemuan ke- 1 mencapai $68 \%$. Pada pelaksanaan siklus I pertemuan ke- 2 siswa yang mencapai ketuntasan atau memperoleh nilai $\geq 75$ sebanyak 12 orang siswa dengan persentase $60 \%$, siswa yang memperoleh nilai $<75$ sebanyak 8 orang siswa atau $40 \%$ dan daya serap siswa $71 \%$. Dari data tersebut dapat dipahami bahwa kemampuan siswa pada materi perdangan internasional mata pelajaran IPS dengan menggunakan model pembelajaran Group Investigation (GI) belum mencapai ketuntasan.

\section{Pelaksanaan Penelitian Siklus II}

\section{Hasil Pengamatan Kegiatan Guru Siklus II \\ Dari penelitian pengamatan kegiatan} guru dalam proses pembelajaran siklus II pertemuan ke- 3 dan ke- 4 sudah sesuai dengan indikator kinerja yang diharapkan. Berikut rekapitulasi hasil pengamatan kegiatan guru dalam proses pembelajaran siklus II.
Tabel 4.14. Rekapitulasi

Hasil Pengamatan kegiatan Guru Dalam Proses Pembelajaran Siklus II

\begin{tabular}{|c|c|c|c|c|c|}
\hline \multirow{2}{*}{ No } & \multirow{2}{*}{ Kategori } & \multicolumn{2}{|c|}{ Pertemuan } & \multirow{2}{*}{$\begin{array}{c}\text { Rera } \\
\text { ta }\end{array}$} & \multirow{2}{*}{ Ket } \\
\hline & & 3 & 4 & & \\
\hline \multirow[t]{2}{*}{1} & Sangat & 32 & 48 & $40 \%$ & \multirow{3}{*}{$\begin{array}{c}\text { Sangat } \\
\text { Baik }+ \\
\text { Baik }= \\
86 \%\end{array}$} \\
\hline & Baik & $\%$ & $\%$ & & \\
\hline 2 & Baik & $\begin{array}{l}48 \\
\%\end{array}$ & $\begin{array}{l}44 \\
\%\end{array}$ & $46 \%$ & \\
\hline 3 & Cukup & $\begin{array}{l}20 \\
\%\end{array}$ & $8 \%$ & $14 \%$ & \multirow{2}{*}{$\begin{array}{l}\text { Cukup + } \\
\text { Kurang } \\
=14 \%\end{array}$} \\
\hline \multirow[t]{2}{*}{4} & Kurang & - & - & - & \\
\hline & Presentase & 100 & 100 & 100 & \\
\hline
\end{tabular}

Berdasarkan data pada tabel 4.13 rekapitulasi hasil pengamatan kegiatan guru dalam proses pembelajaran Siklus II pertemua ke-3 dan ke- 4, sudah meningkat. Hasil rata-rata capaian yang diperoleh pada siklus II telah sesuai dengan ketuntasan yang diharapkan. Hasil rata-rata nilai yang diperoleh pada setiap aspek yakni pada kategori sangat baik memperoleh nilai ratarata $40 \%$, kategori baik $46 \%$, dan kategori cukup $14 \%$. Dengan demikian pelaksanaan kegiatan guru dalam pembelajaran pada siklus II telah sesuai dengan indikator kinerja yang ditetapkan.

\section{Hasil Pengamatan Aktivitas Siswa Siklus II \\ Pengamatan aktivitas siswa dalam pembelajaran yang telah dicapai pada siklus II pertemuan ke- 3 dan ke- 4 direkapitulasi pada tabel 4.16 berikut.}


Tabel 4.17. Rekapitulasi

Pengamatan Aktivitas Siswa Dalam Proses Pembelajaran Siklus II

\begin{tabular}{|c|c|c|c|c|c|}
\hline \multirow{2}{*}{$\begin{array}{l}\mathbf{N} \\
\mathbf{o}\end{array}$} & \multirow{2}{*}{$\begin{array}{c}\text { Katego } \\
\text { ri }\end{array}$} & \multicolumn{2}{|c|}{$\begin{array}{c}\text { Pertemu } \\
\text { an }\end{array}$} & \multirow{2}{*}{$\begin{array}{c}\text { Rera } \\
\text { ta }\end{array}$} & \multirow{2}{*}{$\begin{array}{c}\text { Keterang } \\
\text { an }\end{array}$} \\
\hline & & 3 & 4 & & \\
\hline 1 & $\begin{array}{l}\text { Sangat } \\
\text { Baik }\end{array}$ & $\begin{array}{l}41 \\
\%\end{array}$ & $\begin{array}{l}50 \\
\%\end{array}$ & $45 \%$ & \multirow{2}{*}{$\begin{array}{c}\text { Sangat } \\
\text { Baik }+ \\
\text { Baik }=86 \\
\%\end{array}$} \\
\hline 2 & Baik & $\begin{array}{l}41 \\
\%\end{array}$ & $\begin{array}{l}41 \\
\%\end{array}$ & $41 \%$ & \\
\hline 3 & Cukup & $\begin{array}{l}18 \\
\%\end{array}$ & $\begin{array}{c}9 \\
\%\end{array}$ & $14 \%$ & \multirow{2}{*}{$\begin{array}{c}\text { Cukup }+ \\
\text { Kurang }= \\
14 \%\end{array}$} \\
\hline 4 & Kurang & - & - & - & \\
\hline & $\begin{array}{l}\text { Present } \\
\text { ase }\end{array}$ & 100 & $\begin{array}{c}10 \\
0\end{array}$ & 100 & \\
\hline
\end{tabular}

Berdasarkan data pada tabel 4.16 di atas tampak bahwa selama proses pembelajaran dalam setiap pertemuan pada siklus II siswa sudah memperlihatkan keaktifannya dalam pelaksanaan kegiatan pembelajaran sesuai dengan model pembelajaran Group Investigation (GI). Hal ini terlihat pada rata-rata kegiatan siswa pada siklus II sudah mencapai kategori sangat baik, baik dan cukup. Kegiatan siswa pada kategori sangat baik mencapai nilai rata-rata $45 \%$, kategori baik nilai rata-rata $41 \%$, dan kategori cukup nilai rata-rata mencapai $14 \%$ dengan total nilai kategori sangat baik dan baik mencapai $86 \%$ sedangkan kategori cukup mencapai $14 \%$. Dari capaian data tersebut telah menunjukkan bahwa aktivitas siswa dalam pembelajaran siklus II telah berhasil.

\section{Hasil Pengamatan Motivasi Belajar Siswa Siklus II}

Berikut rekapitulasi hasil presentase motivasi belajar siswa siklus II pertemuan ke-3 dan ke-4 di gambar pada tabel 4.19 sebagai berikut.

Tabel 4.20. Rekapitulasi Hasil Pengamatan Motivasi Belajar Siswa Siklus II

\begin{tabular}{|c|c|c|c|c|c|}
\hline \multirow{2}{*}{ No } & \multirow{2}{*}{ Kategori } & \multicolumn{2}{|c|}{ Pertemuan } & \multirow{2}{*}{$\begin{array}{c}\text { Rera } \\
\text { ta }\end{array}$} & \multirow{2}{*}{ Ket } \\
\hline & & 3 & 4 & & \\
\hline 1 & $\begin{array}{l}\text { Sangat } \\
\text { Baik }\end{array}$ & $45 \%$ & $85 \%$ & $65 \%$ & \multirow{2}{*}{$\begin{array}{c}\text { Sangat } \\
\text { Baik + } \\
\text { Baik = } \\
100 \%\end{array}$} \\
\hline 2 & Baik & $55 \%$ & $15 \%$ & $35 \%$ & \\
\hline 3 & Cukup & - & - & - & \multirow{2}{*}{$\begin{array}{c}\text { Cukup } \\
+ \\
\text { Kurang } \\
=-\end{array}$} \\
\hline 4 & Kurang & - & - & - & \\
\hline & Presentase & 100 & 100 & 100 & \\
\hline
\end{tabular}

Hasil rekapitulasi pengamatan motivasi belajar siswa siklus II tabel 4.19 menunjukkan bahwa siklus II pertemuan ke3 dan ke-4 sudah baik, karena nilai rata-rata dari seluruh pertemuan pada pembelajaran siklus II kategori sangat baik dan kategori baik mencapai nilai rata-rata $100 \%$. Hal tersebut disebabkan karena pada saat pembelajaran siswa terlihat lebih aktif dengan kegiatan pembelajaran, semua siswa melibatkan diri selama berlangsungnya diskusi, siswa aktif bertanya, berani menjawab pertanyaan guru, dan menyumbang ide dan gagasan pada saat diskusi.

\section{Hasil Belajar Siswa Siklus II}

Tes yang diberikan kepada siswa bertujuan untuk mengetahui seberapa besar 
pemahaman siswa mengenai materi perdangan internasional. Tes diberikan dalam bentuk objektif dengan jumlah soal 20 nomor. Nilai hasil belajar siswa siklus II pertemuan ke-3 dan ke-4 secara klasikal dilampiran 20 dan 27 halaman 149 dan 163. Hasil yang didapatkan disajikan pada tabel berikut ini:

Tabel 4.21 Rekapitulasi Hasil Belajar Siswa Siklus II

\begin{tabular}{|c|c|c|c|c|c|c|}
\hline \multirow[b]{2}{*}{ No } & \multicolumn{2}{|c|}{$\begin{array}{c}\text { Jumlah Capaian } \\
\text { Siswa }\end{array}$} & \multirow[b]{2}{*}{$\begin{array}{c}\text { Rent } \\
\text { ang } \\
\text { Nilai }\end{array}$} & \multicolumn{2}{|c|}{ Persentase } & \multirow[b]{2}{*}{ Ket } \\
\hline & $\begin{array}{l}\text { Perte } \\
\text { muan } \\
\text { ke- } 3\end{array}$ & $\begin{array}{c}\text { Pertem } \\
\text { uan } \\
\text { Ke- } 4\end{array}$ & & $\begin{array}{c}\text { Perte } \\
\text { mua } \\
\text { n ke- } \\
3\end{array}$ & $\begin{array}{c}\text { Perte } \\
\text { muan } \\
\text { Ke- } \\
4\end{array}$ & \\
\hline 1 & $\begin{array}{c}4 \\
\text { orang }\end{array}$ & $\begin{array}{c}6 \\
\text { orang }\end{array}$ & $\begin{array}{l}90- \\
100\end{array}$ & $20 \%$ & $30 \%$ & \multirow{7}{*}{$\begin{array}{c}\text { Ber } \\
\text { has } \\
i l\end{array}$} \\
\hline 2 & $\begin{array}{c}6 \\
\text { orang }\end{array}$ & $\begin{array}{c}8 \\
\text { orang }\end{array}$ & $\begin{array}{c}80- \\
89\end{array}$ & $30 \%$ & $40 \%$ & \\
\hline 3 & $\begin{array}{c}7 \\
\text { orang }\end{array}$ & $\begin{array}{c}5 \\
\text { orang }\end{array}$ & $\begin{array}{c}70- \\
79\end{array}$ & $35 \%$ & $25 \%$ & \\
\hline 4 & $\begin{array}{c}2 \\
\text { orang }\end{array}$ & $\begin{array}{c}1 \\
\text { orang }\end{array}$ & $\begin{array}{c}60- \\
69\end{array}$ & $10 \%$ & $5 \%$ & \\
\hline 5 & $\begin{array}{c}1 \\
\text { orang }\end{array}$ & - orang & $\begin{array}{c}50- \\
59\end{array}$ & $5 \%$ & - & \\
\hline \multicolumn{4}{|c|}{ Ketuntasan Klasikal } & $\begin{array}{l}85 \\
\%\end{array}$ & $\begin{array}{l}95 \\
\%\end{array}$ & \\
\hline \multicolumn{4}{|c|}{ Nilai rata-rata kelas } & $\begin{array}{l}79 \\
\%\end{array}$ & $\begin{array}{l}84 \\
\%\end{array}$ & \\
\hline
\end{tabular}

Berdasarkan tabel 4.20 di atas, dapat diketahui bahwa hasil belajar siswa siklus II pertemua ke-3 dan 4 telah mencapai indikator keberhasilan yakni $70 \%$ dari ratarata kelas. Hasil belajar pada siklus II pertemuan ke- 3 siswa yang memperoleh nilai $\geq 75$ sebanyak 17 orang dengan persentase ketuntasan $85 \%$, siswa yang memperoleh nilai $<75$ sebanyak 3 orang siswa dengan persentase $15 \%$, sedangkan daya serap siswa pada pertemuan ke-3 mencapai 79 \%. Pada pelaksanaan siklus II pertemuan ke-4 siswa yang mencapai ketuntasan atau memperoleh nilai $\geq 75$ sebanyak 19 orang siswa dengan persentase $95 \%$, siswa yang memperoleh nilai $<75$ sebanyak 1 orang siswa atau $5 \%$ dan daya serap siswa $84 \%$. Dari data tersebut dapat dipahami bahwa hasil belajar siswa pada materi perdangan internasional mata pelajaran IPS dengan menggunakan model pembelajaran Group Investigation (GI) telah berhasil.

\section{PEMBAHASAN}

\section{1) Hasil Belajar Siswa}

Pemahaman siswa terhadap materi perdagangan internasional pada mata pelajaran IPS dapat diketahui dari hasil tes belajar siswa, pada tabel di bawah ini:

Tabel 4.23. Nilai Hasil belajar Siswa (Capaian Ketuntasan)

\begin{tabular}{|c|l|c|c|c|}
\hline No & $\begin{array}{c}\text { Uraian } \\
\text { Pencapaian } \\
\text { Hasil }\end{array}$ & $\begin{array}{c}\text { Jumlah/ } \\
\text { Nilai } \\
\text { Observa } \\
\text { si Awal }\end{array}$ & $\begin{array}{c}\text { Jumlah } \\
\text { /Nilai } \\
\text { Siklus I }\end{array}$ & $\begin{array}{c}\text { Jumlah } \\
\text { /Nilai } \\
\text { Siklus } \\
\text { II }\end{array}$ \\
\hline 1 & Tuntas & $46 \%$ & $52,50 \%$ & $90 \%$ \\
\hline 2 & Tidak Tuntas & $54 \%$ & $47,50 \%$ & $10 \%$ \\
\hline
\end{tabular}

Berdasarkan pada tabel, terlihat capaian ketuntasan belajar siswa semakin mengalami peningkatan yakni observasi awal dengan capaian ketuntasan $46 \%$ dan yang tidak tuntas $54 \%$. Pada siklus I mengalami peningkatan dari sebelumnya, 
capaian ketuntasan sebesar 52,50\%, dan belum mencapai batas tuntas minimal mencapai 47,50 \%. Pada siklus II terjadi kenaikan persentase dibandingkan siklus I yaitu capaian ketuntasan sebesar $90 \%$ dan $10 \%$ belum mencapai ketuntasan.

\section{2) Hasil Pengamatan Motivasi Belajar Siswa}

Data hasil pengamatan motivasi belajar siswa untuk setiap kategori penilaian pada siklus I dan II dapat ditunjukkan pada tabel berikut ini:

Tabel 4.24. Rekapitulasi Hasil

Pengamatan Motivasi Belajar Siswa

\begin{tabular}{|c|c|c|c|c|c|}
\hline \multirow[b]{2}{*}{$\begin{array}{l}\mathbf{N} \\
\mathbf{0}\end{array}$} & \multirow[b]{2}{*}{$\begin{array}{c}\text { Katego } \\
\text { ri }\end{array}$} & \multicolumn{2}{|c|}{ Siklus } & \multicolumn{2}{|c|}{ Keterangan } \\
\hline & & 1 & 2 & $\begin{array}{c}\text { Siklus } \\
\text { I }\end{array}$ & $\begin{array}{c}\text { Siklus } \\
\text { II }\end{array}$ \\
\hline 1 & $\begin{array}{l}\text { Sangat } \\
\text { Baik }\end{array}$ & - & $\begin{array}{l}6 \\
5 \\
\%\end{array}$ & $\begin{array}{l}\text { Sangat } \\
\text { Baik + } \\
\text { Baik = }\end{array}$ & $\begin{array}{l}\text { Sangat } \\
\text { Baik + } \\
\text { Baik = }\end{array}$ \\
\hline 2 & Baik & $5 \%$ & $\begin{array}{c}3 \\
5 \\
\%\end{array}$ & $5 \%$ & $100 \%$ \\
\hline 3 & Cukup & $\begin{array}{l}77,5 \\
0 \%\end{array}$ & - & $\begin{array}{c}\text { Cukup } \\
+\end{array}$ & $\begin{array}{c}\text { Cukup } \\
+\end{array}$ \\
\hline 4 & Kurang & $\begin{array}{l}17,5 \\
0 \%\end{array}$ & - & $\begin{array}{c}\text { Kuran } \\
g=95 \\
\%\end{array}$ & $\begin{array}{c}\text { Kuran } \\
g=0 \\
\%\end{array}$ \\
\hline
\end{tabular}

Hasil pengamatan menunjukkan terjadinya perubahan pada persentase capaian dari siklus I dan siklus II. Pada siklus I tidak memperoleh kategori sangat baik, kategori baik mencapai $5 \%$, kategori cukup 77,50 \% dan kategori kurang 17,50 \%. Pada siklus II terjadi peningkatan persentase yakni pada kategori sangat baik mencapai $65 \%$, kategori baik mencapai 35, dan tidak memperoleh kategori cukup dan kurang. Dalam pelaksanaan tindakan dari siklus I dan II, diperlukan waktu dan proses agar seluruh siswa dapat berpartisipasi aktif dalam pembelajaran khususnya pada saat diskusi dan presentasi. Siswa melibatkan diri dalam diskusi, baik bertanya maupun menjawab pertanyaan.

\section{3) Hasil Pengamatan Aktivitas Siswa dalam Pembelajaran}

Data hasil pengamatan aktivitas belajar siswa setiap kategori penilaian untuk siklus I dan II, dapat ditunjukkan pada tabel berikut ini:

Tabel 4.25. Hasil Pengamatan Aktivitas Siswa dalam Pembelajaran

\begin{tabular}{|c|l|c|c|}
\hline No & Kategori & Siklus I & Siklus II \\
\hline 1 & Sangat Baik & $12 \%$ & $45 \%$ \\
\hline 2 & Baik & $21 \%$ & $41 \%$ \\
\hline 3 & Cukup & $38 \%$ & $14 \%$ \\
\hline 4 & Kurang & $29 \%$ & - \\
\hline
\end{tabular}

Hasil pengamatan aktivitas siswa dalam belajar menunjukkan peningkatan dari setiap siklus yang dilakukan. Hal ini berarti aktivitas siswa pada saat proses belajar mengajar baik saat diskusi dan presentasi mengalami perubahan yang cukup baik pada setiap aspek, karena siswa menjadi lebih aktif dalam proses pembelajaran, aktif bertanya maupun 
menjawab pertanyaan, dan dalam pelaksanaan diskusi siswa sudah memiliki kesiapan yang baik dalam penyampaian hasil investigasi.

\section{4) Hasil Pengamatan Kegiatan Guru dalam Pembelajaran}

Data persentase capaian untuk setiap kategori penilaian dapat diperoleh dari hasil pengamatan kegiatan guru dalam pembelajaran untuk setiap siklus. Capaian persentase kegiatan guru dalam pembelajaran ditunjukkan pada tabel berikut.

Tabel 4.26. Hasil Pengamatan Kegiatan Guru dalam Pembelajaran

\begin{tabular}{|c|l|c|c|}
\hline No & Kategori & Siklus I & Siklus II \\
\hline 1 & Sangat Baik & $6 \%$ & $40 \%$ \\
\hline 2 & Baik & $22 \%$ & $46 \%$ \\
\hline 3 & Cukup & $38 \%$ & $14 \%$ \\
\hline 4 & Kurang & $34 \%$ & - \\
\hline \multicolumn{4}{|c|}{ Pada tabel di atas, menunjukkan }
\end{tabular}

bahwa kegiatan guru dalam pembelajaran semakin terlihat meningkat seiring dengan pergantian siklus. Dari setiap siklus I dan II mengalami peningkatan yakni pada kategori sangat baik mencapai $6 \%$ meningkat menjadi $40 \%$, kategori baik $22 \%$ meningkat menjadi $46 \%$, kategori cukup 38 $\%$ meningkat mejadi $14 \%$. Terjadinya peningkatan, karena guru sebagai fasilitator dan motivator semakin terlatih dalam menghadapi siswa. Kemampuan guru memberikan motivasi membuat siswa lebih percaya diri, sehingga siswa berani untuk tampil aktif dikelas. Siswa menjadi aktif bila diberikan tugas di depan kelas untuk menyampaikan hasil investigasi kelompok, menjawab pertanyaan, memberikan saran dan tidak sungkan untuk bertanya mengenai pelajaran yang belum dipahami. Proses pembelajaran menjadi menyenangkan bagi guru maupun siswa.

\section{PENUTUP}

\section{A. Simpulan}

Hasil penelitian tindakan kelas menggunakan model pembelajaran Group Investigation (GI) pada mata pelajaran IPS materi perdagangan internasional dapat meningkatkan motivasi dan hasil belajar siswa kelas IV SD Laboratorium UNG.

1. Hasil pengamatan motivasi belajar siswa, ketuntasan pada siklus I sangat baik dan baik sebesar $5 \%$ dan pada siklus II meningkat menjadi $100 \%$.

2. Hasil belajar siswa, ketuntasan belajar siswa pada observasi awal $46 \%$ meningkat pada siklus I sebesar 52,50 $\%$ dan pada siklus II meningkat menjadi $90 \%$.

3. Hasil pengamatan akvitas siswa dalam pembelajaran, ketuntasan pada siklus I pada kriteria sangat baik dan baik mencapai $33 \%$ dan pada siklus II menjadi $86 \%$. 
4. Hasil pengamatan kegiatan guru dalam pembelajaran, ketuntasan pada siklus I kriteria sangat baik dan baik sebesar 28 $\%$ dan pada siklus II meningkat menjadi $86 \%$.

Hasil penelitian tindakan kelas yang telah dilakukan, dapat ditarik sebuah kesimpulan, bahwa pemanfaatan model pembelajaran Group Investigation (GI) dapat meningkatkan motivasi dan hasil belajar siswa, hal ini terbukti dengan adanya peningkatan pada setiap siklus.

\section{B. Implikasi}

Berdasarkan hasil dari penelitian, terdapat beberapa implikasi yang berguna baik secara teoritis maupun praktis dalam meningkatkan motivasi dan hasil belajar siswa pada mata pelajaran IPS sebagai berikut:

1. Implikasi Teoritis

Hasil penelitian ini dapat digunakan untuk memperluas pengetahuan bagi para pembaca khususnya guru tentang pentingnya penerapan model pembelajaran dalam proses belajar mengajar dan dapat sebagai salah satu sumber acuan bagi peneliti lain yang akan mengadakan penelitian lebih lanjut.

\section{Implikasi Praktis}

Penerapan model pembelajaran Group Investigation (GI) pada mata pelajaran IPS dengan materi Perdagangan Internasional sebagai usaha untuk meningkatkan motivasi dan hasil belajar siswa kelas VI SD Laboratorium UNG Kota Selatan Kota Gorontalo. Dengan penerapan model pembelajaran Group Investigation siswa lebih interaktif di saat pembelajaran dan lebih mudah memecahkan permasalahan pada materi yang dipelajari, karena terjadinya interaksi antara siswa dengan siswa maupun antar siswa dengan guru.

\section{Saran}

Berdasarkan simpulan di atas, maka peneliti dapat memberikan saran sebagai berikut:

1. Guru sebaiknya memperhatikan model pembelajaran yang digunakan, yaitu dengan melibatkan siswa secara aktif karena peran guru sebagai fasilitator dan motivator. Salah satu model pembelajaran yang dapat digunakan yaitu model pembelajaran Group Investigation (GI).

2. Dalam pemanfaatan model pembelajaran Group Investigation (GI), sebaiknya siswa dijelaskan secara rinci dahulu, agar pada saat model itu digunakan tidak terjadi kebingungan dan membuang waktu dengan percuma seperti pada siklus I.

3. Dalam penggunaan model pembelajaran Group Investigation (GI) harus ada pembagian waktu kepada setiap kelompok untuk presentasi, agar semua 
kelompok mendapat giliran untuk presentasi di depan kelas.

4. Dalam proses pembelajaran, guru hendaknya memberikan perhatian kepada seluruh siswa agar siswa yang memiliki kemampuan rendah tidak merasa minder dan akhirnya hanya bersikap pasif pada proses pembelajaran yang sedang berlangsung.

5. Guru hendaknya memberikan perhatian kepada permasalahan yang dihadapi oleh siswa, agar dapat meningkatkan kualitas pembelajaran menjadi lebih baik.

6. Siswa hendaknya bisa lebih aktif dalam kegiatan pembelajaran, tidak tergantung kepada guru. Apabila ada yang tidak dimengerti bisa bertanya kepada guru atau temannya yang lebih pandai.

\section{DAFTAR PUSTAKA}

Abdurrahman. 2003. Pendidikan Bagi Anak Berkesulitan Belajar. Jakarta: Rineka Cipta

Arikunto, dkk. 2007. Penelitian Tindakan Kelas. Jakarta: Bumi Aksara

Hamalik Oemar. 2009. Proses Belajar Mengajar. Jakarta: Bumi Aksara

Isjoni. 2009. Pembelajaran Kooperatif. Yogyakarta: Pustaka Pelajar

Kunandar. 2007. Guru Profesional Implementasi Kurikulum Tingkat Satuan Pendidikan (KTSP) dan Persiapan Menghadapi Sertifikat
Guru. Jakarta : Raja Grafindo Persada

Makmun, Abin Syamsudin. 2007. Psikologi Kependidikan; Perangkat Sistem Pengajaran Modul. Cetakan ke 10. Bandung. PT Remaja Rosdakarya

Nurhadi. 2004. Kurikulum 2004 Pertanyaan dan Jawaban. Jakarta: Gramedia Widiasarana Indonesia

Riyanto, Yatim. 2009. Paradigma Baru Pembelajaran. Jakarta: Kencana

Sagala Syaiful. (2003). Konsep dan Makna Pembelajaran. Bandung: Alfabeta

Slavin. 2010. Cooperative Learning. Bandung: Nusa Media

Sobour, Alex. 2003. Psikologi Umum dalam Lintasan Sejarah. Bandung: CV Pustaka Setia

Sri Rumini, dkk 1995.Psikologi Pendidikan.Yoyakarta:Unit Percetakan dan Penerbitan (UPP) UNY.

Sudjana Nana. 2009. Penilaian Hasil Belajar. $\quad$ Bandung: Remaja Rosdakarya

Sunendar Dadang. 2009. Model Pembelajaran Bahasa. Bandung: Remaja Rosda Karya

Suryabrata, Sumadi. 2011. Psikologi Pendidikan. Jakarta: PT Raja Grafindo Persada.

Trianto. 2007. Pembelajaran Kooperatif. Jakarta:Rineka Cipta

Uno, B Hamzah. 2013. Teori Motivasi Dan Pengukurannya. Jakarta: Bumi Aksara

Uzer, Mohamad Usman, 2000. Pembinaan Profesional Guru. Jakarta: Remaja Rosda Karya

Winataputra, dkk. 2003. Model Belajar Mengajar. Depdikbud: Jakarta. 